\title{
What Makes A Franchisee Successful: Attitudes And Pre-Requisites Of Profitable Franchise Partners
}

Christine Gaul, University of Latvia, Latvia

\begin{abstract}
Franchising has gained popularity over the last decades. From a franchisor point of view, expanding a franchise network depends on several key aspects, one of which is the franchisee candidate recruitment and appropriate selection. This paper develops a theoretical franchisee selection model, which is based on an extensive international literature review and then discussed with 33 German-speaking franchise experts, in order to result in an improved and practically oriented model. The findings of this research are numerous and include the closely oriented opinion between academics around the world and interviewed franchise experts in Germany and Austria. Qualitative interviews give an insight in the many facets necessary to consider when evaluating a franchisee candidate. Nevertheless, the complexity of the topic limits the validity of the analysis made in this single paper.
\end{abstract}

Keywords: Franchising; Franchisee Selection

\section{INTRODUCTION}

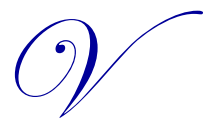

ertical cooperation systems have gained access to countless business sectors and service providers. Within vertical cooperation systems, one channel member takes over power over other channel members and guarantees cooperation (Kotler et al., 2008). Vertically integrated systems keep competing over customers with non-integrated systems (Ahlert et al., 2013). This competitive setting allows dynamic process of change and continuous improvement. Franchising is one example of vertical cooperation systems. Via franchising, cost of production and the respective coordination of it decrease, while flexibility of the business rises (Caves et al., 1976). For an entrepreneur, the reasons opting for being part of a franchise system are foremost a high possibility of gaining superior standard of living, the offer of receiving training on the job, and the chance to being one's own boss, (Bennett et al., 2010) while being backed up by a proven system.

Opting for franchising as expansion strategy, on the one hand allows easy access to capital, rapid market penetration, development of a network distribution system, cooperation with striving entrepreneurs, and quick growth rates (Hoffman et al., 1991; D. Ahlert et al., 2010). On the other hand, it relaxes several other growth constraints a firm may have (Lafontaine, 1992). Nevertheless, several challenges arise when using franchising as an expansion strategy.

One difficulty of network expansion is the challenge of finding the right partners for the systems. Misfitting characters within an organization, which builds upon individual entrepreneurs who operate independently, to a certain extend, may cause enormous damage for the brand, the company, the franchisor, and the franchise network at the same time. Researchers and practitioners have stated that selecting qualified franchisees is perceived the franchisor's single most pervasive operating problem (Clarkin et al., 2006). Franchise partnerships are meant to be win-win situations for everyone involved. For this reason, adequate preparation before the selection process is highly necessary to prevent future losses and a negative climate inside the organization. The ultimate goals of searching suitable candidates serve the purpose to minimize the risk of inadequate selection, to increase the probability of finding the right candidates, and to diminish the component of lucky guessing and gambling for a 
qualified partner (Ahlert et al., 2006). The research question, therefore, is, "Do entrepreneurial abilities, sales abilities, a certain financial background, and leadership abilities lead to an improved franchiseship performance?"

This paper presents one part of a larger project and demonstrates a model for franchisee partner selection. Qualitative research to test sections of the model was conducted and parts of the results are demonstrated in this contribution. The goal is to refine the presented model with the findings of the research and to improve the model for further research. The model is based on an extended international literature review and it will allow a deeper insight into qualifications and criteria necessary for favorable franchisee selection.

As far as limitations in this contribution are concerned, the author points out that, solely, a few parts of the model are tested in this paper. Finally, further testing is necessary to build a strong model for future verification. For this reason, final results are yet to be expected after the entire project will be finalized.

\section{LITERATURE REVIEW}

Amongst numerous types of characteristics a franchise partner should display, one major aspect is the entrepreneurial attitude. Different opinions exist on how much of an entrepreneurial spirit is needed in a franchise business. Some believe that entrepreneurial aspects are absolutely necessary as business risk applies to all parties and has to be dealt with accordingly. Others mention that franchisees are a special type of managers as they do not pursue specific growth strategies (Ketchen, Jr. et al., 2011). Nevertheless, legally the franchisee has an entrepreneurial standing. Practically, the degree of entrepreneurial spirit required to reach mutual goals and to grow the business might depend on the franchise system.

Franchisee selection is a challenge for practitioners, theorists, and academics alike. A direct connection between partner acquisition and future development of franchisees has been established. For this reason, Heußler et al. (2013, p. 57) state that it is highly important to find so-called "hidden characteristics". The group of researchers names personal interviews, estimating entrepreneurial potential, evaluating learning probabilities, observing team player characteristics, and testing soft skills to be relevant steps in the selection process. The process has been researched in several case studies by Altinay and defined through partner-related and task-related selection criteria, where different stages of the selection process put distinct emphasis on certain criteria (Brookes et al., 2011). In another study, Altinay reveals political decision-making as an important base for a franchisor strategy in one participant company. This means "personal goals and benefits of key players, such as country managers and senior development managers, influence the franchising decision-making process" (Altinay et al., 2010, p. 941-942). This statement implies that the process can be a cross-discipline process where not only the top management participates in selection decisions (Altinay, 2006, p. 123).

Stanworth (1995) suggests financial background, energy and enthusiasm, besides other qualifications, to be looked for in franchisee candidates. He states that when picking winners, gut feeling is one factor that often plays a role. Other factors include profit motivation, sales orientation, ability to compete with self-imposed standards, and to make unpopular decisions, as well as ability of dealing with surviving uncertainty. Olm et al. (1988) examines four groups of characteristics - personality/attitude, knowledge/capability, financial capability, and general demographics. The results show that general management skills, previous work experience, and management of personnel were considered the most important aspects for capabilities and knowledge for franchisees. As far as personality and attitude is concerned, industry, motivation and perseverance were named top three. In the category financial indicators, respondents consider credit, personal cash and personal assets as most relevant for selecting a candidate. Olm et al. examined also other characteristics, which show that reputation, family commitment, and health are highly relevant for selecting franchisees. Out of all factors considered, personality was ranked highest, financial second, skills third, and background last (Olm et al., 1988).

It soon becomes clear that different researchers consider a large variety of selection criteria to be relevant. This may depend on the variety of sectors surveyed, the size of the company, the age, and the internal strategy (Rahatullah et al., 2009). Within the proposed model, these select criteria are categorized and formed into a framework where the outcome is the performance of the franchiseship. 


\section{Franchisee Selection Model}

Taking relevant literature into consideration, a model for successful franchisee selection is developed. Within this model, individual abilities and characteristics are bundled to display improved performance of the franchiseship. The model seeks input characteristics to find candidates with higher potential for success, which imply higher profits for franchisors and franchisees alike. The proposed model, as displayed in Figure 1, uses entrepreneurial, leadership, and sales abilities, as well as financials background. The author assumes these characteristics to influence the performance and also the success of the future franchisee.

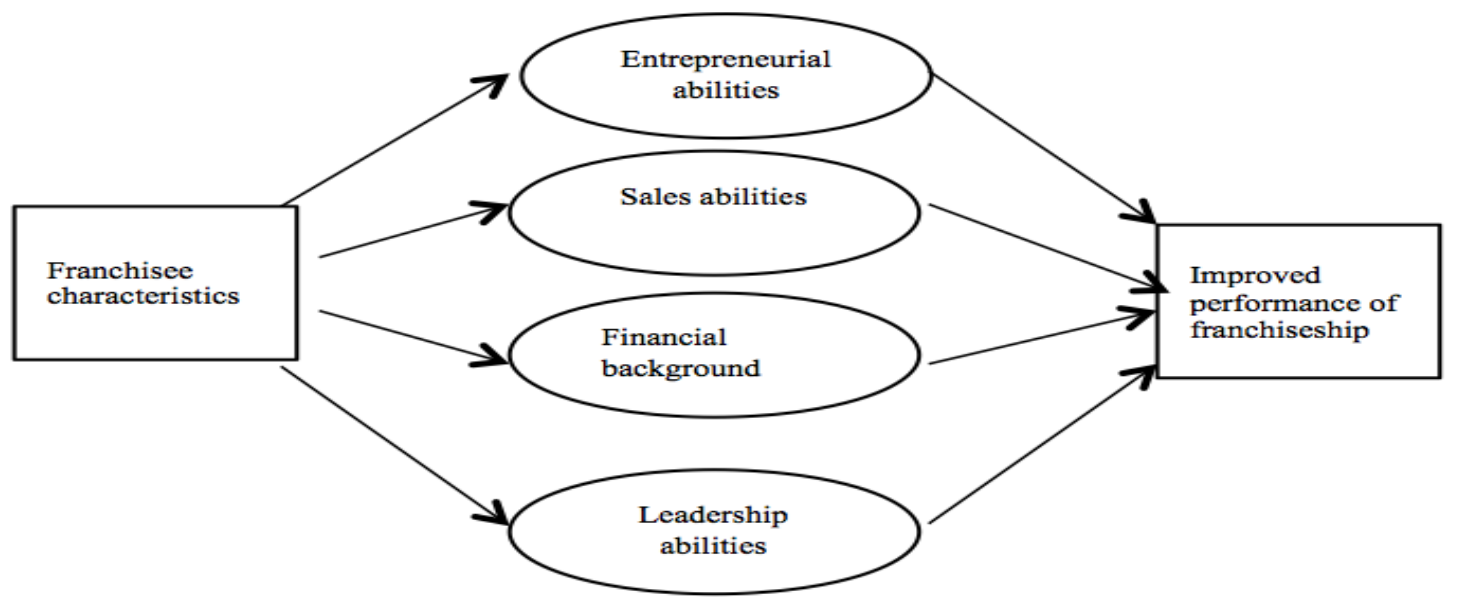

Figure 1: Franchisee Selection Model

The goal of this paper is finding skills and requirements of promising candidates to define a franchisee partner with above average performance potential. Favorable franchisee selection shall spur promising franchise partnership in the future for a win-win situation for both, franchisors and franchisees.

\section{METHOD}

Data were collected during February and March 2014. Interviews, including closed and open questions, which were executed with German and Austrian franchise experts. Experts are associated with the German Franchise Association, or members of committees founded by the German Franchise Association. Members of the committees are either consultants or decision-makers in the franchisee selection process of their respective companies. Consultants are lawyers and general business consultants. A total of 33 answers were counted. The interviews were either oral via telephone conversation, or on a written basis via emailed questionnaires. The openended questions were taken into account for this contribution and analyzed by comparing answers.

\section{RESULTS AND DISCUSSION}

When asked about the success of franchisees, two types were suggested - investor and active franchisees. Twenty-eight experts named franchisees, who actively participate in the business and its daily operations, to be more successful than investor franchisees. Nevertheless, the answers for specific companies or systems may differ from the general view, as investor franchisees are said to be more financially stable and have a larger likelihood of buying necessary services to improve the business, compared to actively participating franchisees.

When asked about a self-made definition of a successful franchisee, a large range of descriptions was given. Analyzing the answers, the author grouped the most repeatedly named descriptions into four categories satisfaction in partnership, sales and profit, common goals, and system conformity. 
The first group - satisfaction in partnership - contains various aspects of harmony, equal partnership, value toward the other party, and feeling well taken care of. According to Lusch (1976, p. 139), dissatisfaction in partnership leads to "additional legislation to regulate franchisor-franchisee relations." Also, high levels of satisfaction and trust trigger exchange partner cooperation and relational congruence (Weaven et. al, 2014, p. 100 citing Payan et al., 2005). For this reason, the result of mentioning satisfaction as a top four leading category is justifiable and confirms previous results of the mentioned authors.

The second group - sales and profit - are two financial aspects that are named frequently when defining a successful franchisee. However, 'profits' are more relevant as the number of sales may not classify a profitable business. In addition, 'sustainable profits' keep the business going and allows return on investment in the longer run. Furthermore, 'investments for future business potential and growth' are named frequently. Nevertheless, most experts mention, that 'sales' and 'profit' together form a successful franchisee.

The third group is common goals. Most interviewees name 'working together' and 'being actively involved in the system' as reasons for being successful. Pushing for 'mutual goals' and 'working hard' are elements of success, as well as 'continuous motivation' for oneself and others. The "we-thinking" has to prevail as the system can only be successful if its partners are successful. Improving the existing concept by a common effort can lead to a more efficient concept. One answer by an expert expresses social activities outside the system to be an indicator for a successful franchisee. The interviewee opinionates, that community support shows engagement with others and spurs mutual goal orientation. The group of 'common goals' supplies most feedback of all four groups and can therefore be recognized as highly relevant to the definition of a successful franchisee.

The fourth group is system conformity. Interviewees mention a 'common brand and appearance' as a sign of belonging together and pushing success. Being 'loyal to the system' and 'adhering to its rules and regulations' is considered a step toward favorable outcomes, which implies trust and strong belief in the actions of the headquarter instructions. It shows trustworthiness amongst German and Austrian systems. 'Identification with the system', 'living the system', 'walking the same walk, and talking the same talk' makes franchising a strong player and allows win-win situations for all parties. Table 1 summarizes all four main categories.

Table 1: Own Definition Of Successful Franchisee Defined By Franchise Experts

\begin{tabular}{|c|c|c|c|}
\hline Satisfaction In Partnership & Sales And Profit & Common Goals & System Conformity \\
\hline Happy entrepreneur & Sales oriented & $\begin{array}{l}\text { Communicative and } \\
\text { networking }\end{array}$ & Adheres to CI \\
\hline $\begin{array}{l}\text { Feels well taken care of by } \\
\text { franchisor }\end{array}$ & Economic success & $\begin{array}{l}\text { Strong in applying business } \\
\text { concept }\end{array}$ & $\begin{array}{l}\text { Trusts in concept and its } \\
\text { application }\end{array}$ \\
\hline $\begin{array}{l}\text { Seeing franchise system as } \\
\text { family }\end{array}$ & Economic success of partners & Good team player & $\begin{array}{l}\text { Exited franchisee with strong } \\
\text { brand and system loyalty }\end{array}$ \\
\hline \multirow[t]{10}{*}{ No conflict with franchisor } & $\begin{array}{l}\text { More successful than } \\
\text { competitor }\end{array}$ & $\begin{array}{l}\text { Pro active, contributes with } \\
\text { ideas, entrepreneurial spirit }\end{array}$ & Follows the system \\
\hline & Profitable, solid business & $\begin{array}{l}\text { Engages in social activities } \\
\text { outside work }\end{array}$ & Loyal to the system \\
\hline & $\begin{array}{l}\text { Ready to invest to grow into } \\
\text { next life-cycle }\end{array}$ & Supports other franchisees & Identification with system \\
\hline & $\begin{array}{l}\text { Economically satisfied } \\
\text { partners, who recommend } \\
\text { the system }\end{array}$ & $\begin{array}{l}\text { Ambitious, goal oriented, } \\
\text { willing to accept criticism }\end{array}$ & $\begin{array}{l}\text { System conform behavior, } \\
\text { loyalty to the system }\end{array}$ \\
\hline & Sustainable profit & $\begin{array}{l}\text { Interactive exchange of } \\
\text { experience }\end{array}$ & Follows rules of the system \\
\hline & $\begin{array}{l}\text { Makes above average profit } \\
\text { and pays above average } \\
\text { royalties }\end{array}$ & $\begin{array}{l}\text { Puts entrepreneurial mission } \\
\text { and visions in action }\end{array}$ & \\
\hline & & Continuous motivation & \\
\hline & & Motivates staff & \\
\hline & & $\begin{array}{l}\text { Putting system criteria in } \\
\text { action }\end{array}$ & \\
\hline & & $\begin{array}{l}\text { Suggests possible } \\
\text { improvements of the system }\end{array}$ & \\
\hline
\end{tabular}


Another question in the survey asked about decisive selection criteria when recruiting new franchisees. The author again grouped the most frequently named answers into four major categories - sales abilities, financial background, entrepreneurial talents, and leadership abilities.

The first group is sales abilities and relates to sales and profit from the question before. The ability to 'close sales', 'being strong in sales', 'having sales knowledge and experience' and 'being a sales person or professional' are named most often when defining highly important selection criteria. It shows that although the franchisee is an entrepreneur, busy with management and strategy of the company, experts suggest that franchisors look at the ability to sell products or services themselves. This qualification demonstrates the necessity as it was named frequently.

The second group refers to financial background of a franchisee candidate. Having 'sufficient financial funds' to start the business is named a decisive qualification for starting out. Sufficient funds are the base of starting up and continuing, as necessary investment may range from a few hundred Euro to over a million Euro. The entrepreneur needs enough money to cover at least the period until operating with a profit. If a candidate does not possess sufficient funds, 'third-party' financing or 'borrowing' must be possible.

The third group is entrepreneurial talents and displays most extensive descriptions, some of which are repeatedly named. They include 'entrepreneurial talent', 'spirit', and 'thinking'. In addition, 'business knowledge' and 'experience' are also counted numerous times. Furthermore, 'being active', 'willing to work hard', 'being committed', and 'standing conflicts' are also mentioned when considering decisive selection criteria. The collection of characteristics describes a 'strong fighter mentality' and puts emphasis on independent work for future benefits.

The fourth group is leadership abilities and is named several times as crucial criteria. Franchisees are seen 'objective', 'assertive', 'communicative', and 'educated leaders' who can 'train others' and are 'trustworthy'. They are meant to 'lead their staff and clients by charisma and sympathy'. Future, franchisees should have 'knowledge and experience', as well as they should 'lead by example'. Followers shall 'acknowledge the leader's expertise', as he or she shall be 'transparent and fair'. Table 2 summarizes all four main categories. 
Table 2: Decisive Selection Criteria Defined By Franchise Experts

\begin{tabular}{|c|c|c|c|}
\hline Sales Abilities & Financial Background & Entrepreneurial Talents & Leadership Abilities \\
\hline Sales knowledge & $\begin{array}{l}\text { Minimum } 10 \text { thousand Euro } \\
\text { equity }\end{array}$ & Strong self-motivation & Leadership abilities \\
\hline Sales experience & $\begin{array}{l}\text { Equity and possibility to } \\
\text { finance }\end{array}$ & Stands conflicts & Personnel leadership \\
\hline Strong closing sales & Equity/ financial securities & Business knowledge & $\begin{array}{l}\text { Leadership experience, } \\
\text { including work experience/ } \\
\text { experience in the business } \\
\text { sector }\end{array}$ \\
\hline $\begin{array}{l}\text { Sales and organization } \\
\text { experience }\end{array}$ & Has sufficient financial funds & Entrepreneurial motivation & $\begin{array}{l}\text { Engage in sympathy having } \\
\text { charisma }\end{array}$ \\
\hline Able to acquire clients & Financial liquidity & Growth philosophy & Leading \\
\hline Strong sales abilities & Sufficient resources & Adaptive, understanding & Objective \\
\hline Sales person & Sufficient own resources & Discipline & $\begin{array}{l}\text { Trustworthy without being } \\
\text { critical }\end{array}$ \\
\hline Sales experience & & $\begin{array}{l}\text { Implement instructions and } \\
\text { keep motivation up }\end{array}$ & Able to train \\
\hline Sales oriented & & Business sector experience & Communicative \\
\hline Sales abilities & & $\begin{array}{l}\text { Experience in entrepreneurial } \\
\text { sprite }\end{array}$ & Assertive \\
\hline Talented in sales & & Realization of actions & Leadership abilities \\
\hline Sales professional & & Business knowledge & Service oriented \\
\hline \multirow{18}{*}{ Willing to work in operations } & & Broad minded and outgoing & Leadership experience \\
\hline & & Basic business knowledge & Manage and lead staff \\
\hline & & Openness & Team player in a network \\
\hline & & $\begin{array}{l}\text { Experience in the business } \\
\text { sector }\end{array}$ & $\begin{array}{l}\text { Sufficiently educated/trained } \\
\text { for the technical part of the } \\
\text { job }\end{array}$ \\
\hline & & Proactive not reactive & Leadership experience \\
\hline & & Active & Good communicator \\
\hline & & $\begin{array}{l}\text { Needs more continuity than he } \\
\text { thinks }\end{array}$ & Fair and transparent \\
\hline & & $\begin{array}{l}\text { Entrepreneurial thinking/ } \\
\text { spirit }\end{array}$ & Trustworthy \\
\hline & & Working independently & Leadership qualities \\
\hline & & Expertise & Leadership competencies \\
\hline & & Reliability & \\
\hline & & Equilibrated partnership & \\
\hline & & $\begin{array}{l}\text { Needs potential to be } \\
\text { entrepreneur }\end{array}$ & \\
\hline & & Has to enjoy work & \\
\hline & & Social competencies & \\
\hline & & Friendly, people oriented & \\
\hline & & Committed & \\
\hline & & $\begin{array}{l}\text { Willing to listen and apply } \\
\text { franchise suggestions }\end{array}$ & \\
\hline
\end{tabular}

\section{CONCLUSION}

General franchisee selection can be improved by the findings presented in this paper. The results show a slightly different picture than overall international literature assumes. However, the findings fit the proposed model and even increase the number of the most relevant characteristics by sytem conformity, the need of common goals, and satisfaction in the partnership. Nevertheless, some limitations apply. The possibility that German and Austrian experts may have an average opinion different than other nationalities may be due to the relatively small number of 33 answers. Although numerous experts mentioned that their answers might differ if asked for a specific business 
type. However, this study made no difference of selection between business sector and displays a general overview of expert opinions.

Feedback from the survey shows the definition of successful franchisees defined by experts can be categorized into four groups - satisfaction in partnership, sales and profit, reaching goals together, and system conformity. The second categorization is sale abilities, financial background, entrepreneurial talents, and leadership abilities. The definition of the groups shows that financial data and being profitable at the end are seen most relevant when discussing either improved performance of franchiseship, business operations, or successful business partners. Further relevant criteria for a future franchisee are entrepreneurial qualities, as well as leadership, conformity, satisfaction, and teamwork attitudes.

Overall, the study has shed light into relevant franchisee selection criteria and showed that the model, which is based on franchise literature and tested on experts, can temporarily be accepted. In the future, the model in this paper will be adapted to fit a more complex set of criteria. The final goal is a tested and verified model for application in practical business operations during franchisee selection processes.

\section{AUTHOR INFORMATION}

Christiane Gaul holds a Bachelor of Arts in Spanish and a Bachelor of Science in International Business from the College of Charleston, South Carolina (USA), as well as a Master of Business Administration and a Master of Arts in Latin American and Caribbean Studies from Florida International University, Florida (USA). She decided to dedicate her Ph. D. research at the University of Lativa, Riga (Latvia) to international franchising, while working actively in the private franchise sector in Germany.

\section{REFERENCES}

Ahlert, D., \& Ahlert, M. (2010). Franchising und Cooperation - Das Management kooperativer Unternehmensnetzwerke Lebensmitt., Frankfurt am Main: Deutscher Fachverlag.

Ahlert, M., Brock, C., \& Evanschitzky, H. (2006). Franchisenehmerselektion am Beispiel deutscher Franchisesysteme, Muenster.

Ahlert, D., \& Schefer, B. (2013). Management Summary:'The Liberation of the Value Chain from Cartel-Law Restraints'. Vertical Price Coordination and Brand Care - Springer Briefs in Business, pp.59-70.

Altinay, L., 2006. Selecting Partners in an International Franchise Organisation. International Journal of Hospitality Management, 25(1), pp.108-128. Available at: http://linkinghub.elsevier.com/retrieve/pii/S0278431905000162 [Accessed July 4, 2012].

Altinay, L., \& Okumus, F. (2010). Franchise Partner Selection Decision Making. The Service Industries Journal, 30(6), pp.929-946.

Bennett, S., Frazer, L., \& Weaven, S. (2010). What Prospective Franchisees Are Seeking. Journal of Marketing Channels, 17(1), pp.69-87.

Brookes, M., \& Altinay, L. (2011). Franchise Partner Selection: Perspectives of Franchisors and Franchisees. Journal of Services Marketing, 25(5), pp.336-348.

Caves, R. E., \& Murphy, W. F. I. (1976). Franchising: Firms, Markets, and Intangible Assets. Southern Economic Journal, 42(4), pp.572-86.

Clarkin, J. E., \& Swavely, S. M. (2006). The Importance of Personal Characteristics in Franchisee Selection. Journal of Retailing and Consumer Services, 13(2), pp.133-142.

Heußler, T., Ahlert, M., \& Rath, I. (2013). Beziehungsentwicklung in Franchisesystemen, Muenster. Available at: http://www.franchising-undcooperation.de/sites/default/files/redaktion/pdf/beziehungsentwicklung_2013_heusslerahlertvrath_vout.pdf [Accessed December 5, 2013].

Hoffman, R. C., \& Preble, F. (1991). Franchising: Selecting a Strategy for Rapid Growth. Long Range Planning, 24(4), pp.74-85.

Ketchen, Jr., D. J., Short, J. C., \& Combs, J.G. (2011). Is Franchising Entrepreneurship? Yes, No, and Maybe So. Entrepreneurship Theory and Practice, 35(3), pp.583-593.

Kotler, P., \& Keller, K. L. (2008). Marketing Management 13th editi. M. Sabella \& L. Judy, eds., Upper Saddle 
River, New Jersey: Prentice Hall.

Lafontaine, F. (1992). Agency Theory and Franchising: Some Empirical Results. The RAND Journal of Economics, 23(2), p.263.

Lusch, R. (1976). Franchisee Satisfaction: Causes and Consequences. International Journal of Physical Distribution \& Materials Management, 7(3), pp.128-140.

Olm, K. W., Eddy, G. G., \& Adaniya, A. R. (1988). Selecting Franchisees Prospects. In 2nd Annual International Society of Franchising Conference. San Francisco, California: International Society of Franchising, pp. 120.

Payan, J. M., \& McFarland, R. G. (2005). "Decomposing influence strategies: argument structure and dependence as determinants of the effectiveness of influence strategies in gaining channel member compliance", Journal of Marketing, Vol. 69 No. 3, pp. 66-79.

Rahatullah, M. K., \& Raeside, R. (2009). The Dynamism of Partner Selection Criteria in Franchising. SAM Advanced Advertising Management Journal, 74(4), pp.36-46.

Stanworth, J. (1995). Developing a Diagnostic Questionnaire as an Aid to Franchisee Selection. International Franchise Research Centre - Special Studies Series, 6, pp.1-13.

Weaven, S., Grace, D., Dant, R., \& Brown, J.R. (2014). Value creation through knowledge management in franchising: a multi-level conceptual framework. Journal of Services Marketing, 28(2), pp.97-104. 